\title{
Topography changes and thermal distribution at the Kelud crater after the 2014 Plinian eruption
}

\author{
Wahyudi ${ }^{1}$, Ari Setiawan', Heriansyah Putra ${ }^{2}$, Herlan Darmawan $^{1 *}$, Imam Suyanto ${ }^{1}$, Irwan Meilano ${ }^{3}$, \\ Irzaman ${ }^{4}$, Maria Evita ${ }^{5}$ Mitra Djamal', M. Yasin', Nina Siti Aminah', Perdinan', Retna Apsari ${ }^{6}$, Wahyu \\ Srigutomo ${ }^{5}$ and Wiwit Suryanto ${ }^{1}$ \\ ${ }^{1}$ Laboratory of Geophysics, Department of Physics, Faculty of Mathematics and Natural Sciences, Universitas Gadjah \\ Mada, Yogyakarta , Indonesia \\ ${ }^{2}$ Department of Civil Engineering and Environtment, Faculty of Engineering, Bogor Agricultural University, \\ Indonesia \\ ${ }^{3}$ Geodesy Research Group, Faculty of Earth Science and Technology, Bandung Institute of Technology, Indonesia \\ ${ }^{4}$ Department of Physics, Faculty of Mathematics and Natural Sciences, Bogor Agricultural University, Indonesia \\ ${ }^{5}$ Department of Physics, Faculty of Mathematics and Natural Sciences, Bandung Institute of Technology, Indonesia \\ ${ }^{6}$ Department of Physics, Faculty of Science and Technology, Airlangga University, Surabaya, Indonesia. \\ ${ }^{7}$ Department of Geophysics and Meteorology, Faculty of Mathematics and Natural Sciences, Bogor Agricultural \\ University, Indonesia
}

Received: 2020-02-03 Accapted: 2020-11-24

Keywords:

Kelud volcano; erosion; deposition; Crater lake; thermal distribution

Correspondent email: herlan_darmawan@mail.ugm.ac.id

\begin{abstract}
Topography of a volcano crater can change due to endogenic processes such as deformation or eruption, or surface processes. Erosion and deposition are surface processes that may occur and gradually change the slope of the inner volcano crater. Here, we investigated erosion and deposition processes that occurred in the Kelud crater after the 2014 plinian eruption. We used high-resolution Digital Elevation Models (DEMs) and orthomosaic images derived by drone photogrammetry that acquired between September 2018 and July 2019. We obtained hundreds of aerial images which were reconstructed to obtain 3D models of Kelud's crater by using Structure from Motion (SfM) technique. Results show erosions at alluvial fans that dominantly located at the east valleys of Kelud crater. The erosion removed the volcanic materials up to $-5 \mathrm{~m}$ which transported and deposited close to the vicinity of the Kelud crater. The deposition process causes the increase of the Kelud crater lake up to $3 \mathrm{~m}$. Moreover, we also mapped the thermal distribution of the Kelud crater lake by using low cost thermal camera. Our thermal investigation is able to identify some hotspots at the vicinity of the Kelud crater lake with range temperature of $43.7^{\circ} \mathrm{C}-55.3^{\circ} \mathrm{C}$, while the average apparent temperature of the Kelud crater lake is $\sim 29^{\circ} \mathrm{C}$. This high temperature area may indicate underwater active fractures that continuously release volcanic gasses which leads to convection heat transfer through Kelud's water lake.
\end{abstract}

O2020 by the authors. Licensee Indonesian Journal of Geography, Indonesia.

This article is an open access article distributed under the terms and conditions of the Creative Commons

Attribution(CC BY NC) licensehttps://creativecommons.org/licenses/by-nc/4.0/.

\section{Introduction}

The slope of an inner volcano crater is often subjected to topography changes as rainfall or strong wind may erode some volcaniclastic materials and transport them in a lower elevation or crater floor (Fisher \& Smith, 1991). The transported materials may be gradually deposited at the crater lake, increases the crater lake's water level and causes crater flood, such occurred in Aniakchak caldera lake, Alaska (Waythomas, 2001). In some cases, progressive deposition in the crater lake floor of an active volcano can block the volcanic gas bubble during magma ascending, increases water lake's temperature, causes gas overpressure and may trigger a steam-dominated or hydrothermal eruption at the volcano crater lake (Gunkel, Beulker, Grupe, \& Viteri, 2008; Mastin \& Witter, 2000), suggesting the potential hazard of crater lake in an active volcano, such as the crater lake of Kelud volcano,
Indonesia. The eruption of Kelud crater lake in 1919 produced hot mud lahars that devastating the flank areas and claimed thousands of fatalities (Nawiyanto \& Sasmita, 2019).

Kelud volcano (1731 m.a.s.l) is an active stratovolcano that located in the district of Kediri, East of Java, Indonesia and frequently erupts with Volcanic Explosivity Index (VEI) of 2 - 4 since 1000 (Hidayati et al., 2018). In 2007, a crater lake occupied in the middle of Kelud crater. The average temperature of Kelud crater lake was about $40^{\circ}$ and dramatically increased up to $78^{\circ} \mathrm{C}$ in the early of November 2017, which followed by a new lava dome formation and phreatic eruptions. The new lava dome has diameter of $489 \mathrm{~m}$ and height of $216 \mathrm{~m}$ (Hidayati, Basuki, Kristianto, \& Mulyana, 2009). The lava dome was destroyed by large Plinian eruption in 2014 that produced volcanic column ash 
of $\sim 27 \mathrm{~km}$ and changed the morphology of Kelud crater significantly (Hidayati et al., 2009; Maeno et al., 2016). The eruption caused 7 fatalities due to the volcanic ash hazard, damaged some infrastructures, and disrupted the air traffic that causing economy loss up to 392 Billion rupiahs (Goode, Handley, Cronin, \& Abdurrachman, 2018; Kasbani et al., 2019).

Currently, the activity of Kelud volcano is normal and some area around Kelud crater is opened for tourism object, except for the area of Kelud crater lake which hazardous and forbidden for tourism. However, monitoring of topographic changes that can cause deposition at the crater lake and thermal distribution is important to identify future potential hazards. Here, we conducted the first study of topographic changes and thermal distribution at Kelud crater after the 2014 Plinian eruption.

We used drone photogrammetry which widely used for volcano monitoring (James et al., 2020) such as topography changes at active volcanoes (Darmawan, Walter, Brotopuspito, Subandriyo, \& Nandaka, 2018; Darmawan, Walter, Richter, \& Nikkoo, 2017), structural weakening at active lava dome (Darmawan, Walter, Troll, \& Budi-Santoso, 2018), caldera instability (Derrien, Peltier, Villeneuve, \& Staudacher, 2020), lava flow monitoring (De Beni, Cantarero, \& Messina, 2019), and even volcanic gas measurement (McGonigle et al., 2008). We acquired high-resolution aerial images of Kelud crater on September $11^{\text {th }}, 2018$ and July $16^{\text {th }}$, 2019 for topography changes analysis. The drone images were processed by applying Structure from Motion (SfM) algorithm (Szeliski, 2010) to reconstruct high resolution Digital Elevation Model (DEM) and orthomosaic of Kelud crater. Moreover, we modified our drone by attaching a lowcost thermal camera to map the thermal distribution of Kelud crater lake. This paper highlights the topography changes due to erosion and deposition and thermal deposition that may correlate to some underwater active fractures at the Kelud crater lake.

\section{The Methods}

\section{Drone photogrammetry data acquisition}

Topography mapping at Kelud crater was conducted by using drone photogrammetry technique. The drone field campaigns were realized on 11 September 2018 and on 16 July 2019 (during summer season) by using DJI phantom 4 that attached by 12 mega pixel camera. The drone flew at average altitude of $1290 \mathrm{~m}$ (50 m above the Kelud crater lake). During the mission, the camera that attached below the drone captured around 154 and 669 images for the 2018 and the 2019 field campaigns, respectively. The number of aerial images between 2018 and 2019 has large difference as the 2018 drone was set into autonomous flight mode that consume more battery, while the 2019 drone was controlled manually and could capture more images. As limited and hazardous access in the inner slope of the Kelud crater, we did not acquire ground control datasets and rely on the GPS coordinate system that automatically attached on the drone images for georeferenced processing.

\section{Digital Elevation Model and orthomosaic generation}

We used Structure from Motion (SfM) technique (Szeliski, 2010) that implemented in agisoft photoscan software to reconstruct $3 \mathrm{D}$ model based on the $2 \mathrm{D}$ drone images. The drone images of the 2018 and the 2019 dataset were all imported as all of the images have good quality and high visibility. After imported the images, 3D sparse point clouds were reconstructed by detecting and matching some key points of the images. During 3D sparse point cloud reconstruction, we chose image alignment tools and set up the accuracy parameter to moderate. Then, 3D dense point clouds were reconstructed by estimating the camera position and calculating the depth information of the camera. For 3D dense point cloud reconstruction, we set quality and depth filtering parameters to "moderate". We chose moderate as it can reduce computational time and has good quality. The 3D dense point clouds were exported and filtered in cloud compare software to remove the outliers. Afterward, 3D point cloud registration was conducted by manually picking similar stable points in master and slave 3D point clouds. We chose the 2018 3D point cloud as the master and the 2019 3D point cloud as the slave in Cloud Compare Software. We obtained RMSE of $\sim 1.4 \mathrm{~m}$ for $3 \mathrm{D}$ point cloud registration which is sufficient for erosion and deposition mapping at Kelud crater lake.

The filtered 3D point clouds were then interpolated in ArcGIS software to analyze surface profile changes and to visualize the data. In addition, high resolution photomosaic images of the 2018 and 2019 Kelud crater were produced with resolution of $0.08 \mathrm{~m}$. The high-resolution photomosaic images of Kelud crater can provide detail visual analysis of erosion and sedimentation processes in the Kelud crater.

\section{Topographic changes analysis}

The registered 3D point cloud that acquired in September 2018 and July 2019 were exported to analyze the topographic changes at the Kelud crater. We used Multiscale Model to Model Cloud Comparison (M3C2) tools (Lague, Brodu, \& Leroux, 2013) that freely available in cloud compare software. This $\mathrm{M} 3 \mathrm{C} 2$ tools is robust to calculate height differences or distance between two datasets of 3D point clouds. Here, we set the 11 September 2018 as the master data and the 16 July 2019 as the slave data. The resulted height differences were exported, interpolated, and overlapped with the 16 July 2019 orthomosaic image for data visualization.

\section{Thermal investigation}

We also conducted thermal investigation of the Kelud crater lake on 16 July 2019 by using mobile FLIR camera that attached on a mobile phone. The data acquisition was conducted during night around 01:00 a.m. to avoid background noise due to sunlight. The mobile FLIR camera is very simple and light, low cost, and can provide rapid information regarding the apparent temperature of the Kelud crater lake. Even though, the camera has low resolution and accuracy, our thermal images can show some results of thermal distribution at Kelud crater lake.

\section{Result and Discussion}

\section{Topography changes of the inner Kelud crater slope}

Our photomosaic drone image clearly describes significant change of the topography of the Kelud crater between 2018 and 2019. In September 2018, the Kelud crater lake has a major diameter of $\sim 400 \mathrm{~m}$. The lake is surrounded by some alluvial fans as observed in location 1 and 2 (Fig. 1c and e). We infer that the alluvial fans form progressively 
during rainy seasons between 2014 and 2018 as high resolution of satellite image shortly after the 2014 Plinian eruption was not detected any alluvial fan deposit (Maeno et al., 2016). Rain waters between 2014 and 2018 might gradually transport the unconsolidated volcanic materials, which mostly consists of pumice-rich Pyroclastic Density Currents deposits (Maeno et al., 2016), at the upper steep slope of Kelud crater to the Kelud crater floor and formed alluvial fans.

In 2019, erosion and deposition occur massively at the alluvial fans, especially at the eastern part of the valley, and at the vicinity of the crater lake. Our photomosaic drone image shows erosion processes that gradually transported the volcanic materials at the north west (loc 1 in Figure. 1c and d) and at the north east (loc 2 in Figure. 1e and f) alluvial fans. The erosion gradually reduces the volcanic materials up to $8 \mathrm{~m}$ distance, which then transports and deposits at the Kelud crater lake with width of $4 \mathrm{~m}$ (Figure. 1c and d). Similar processes occur at the north east alluvial fan where volcaniclastic materials are deposited with maximum width of $8 \mathrm{~m}$ (Figure. 1e and f). Our drone observation also shows that the volume of the Kelud crater lake increases as identified by increasing of crater lake wide up to $20 \mathrm{~m}$ (Figure. 1e and f).

Comparison between the 2018 and 2019 high resolution Digital Elevation Model of Kelud crater can provide information of elevation changes due to erosion and sedimentation processes. Cross section of surface profiles line $\mathrm{p}-\mathrm{q}$ and $\mathrm{r}$-s clearly describes the massive erosion process up to $-2.5 \mathrm{~m}$ at the north west alluvial fan and $-2 \mathrm{~m}$ at the north east alluvial fan, which cause sedimentation at the crater lake (Figure. 2). The water level of the Kelud crater also increases up to $3 \mathrm{~m}$ (Figure. $2 \mathrm{c}$ and d). Further analysis of height difference between 2018 and 2019 3D point clouds provide spatial distribution of erosion and sedimentation at Kelud crater (Figure. 3). Most of erosion occurred at the steep eastern slope valley of Kelud crater $\left(>40^{\circ}\right)$ with material loss up to $-5 \mathrm{~m}$ (blue area in Figure 3. While, sedimentation have added some volcanic materials up to $5 \mathrm{~m}$ (red area in Figure. $3)$ at the northern part of Kelud crater lake.
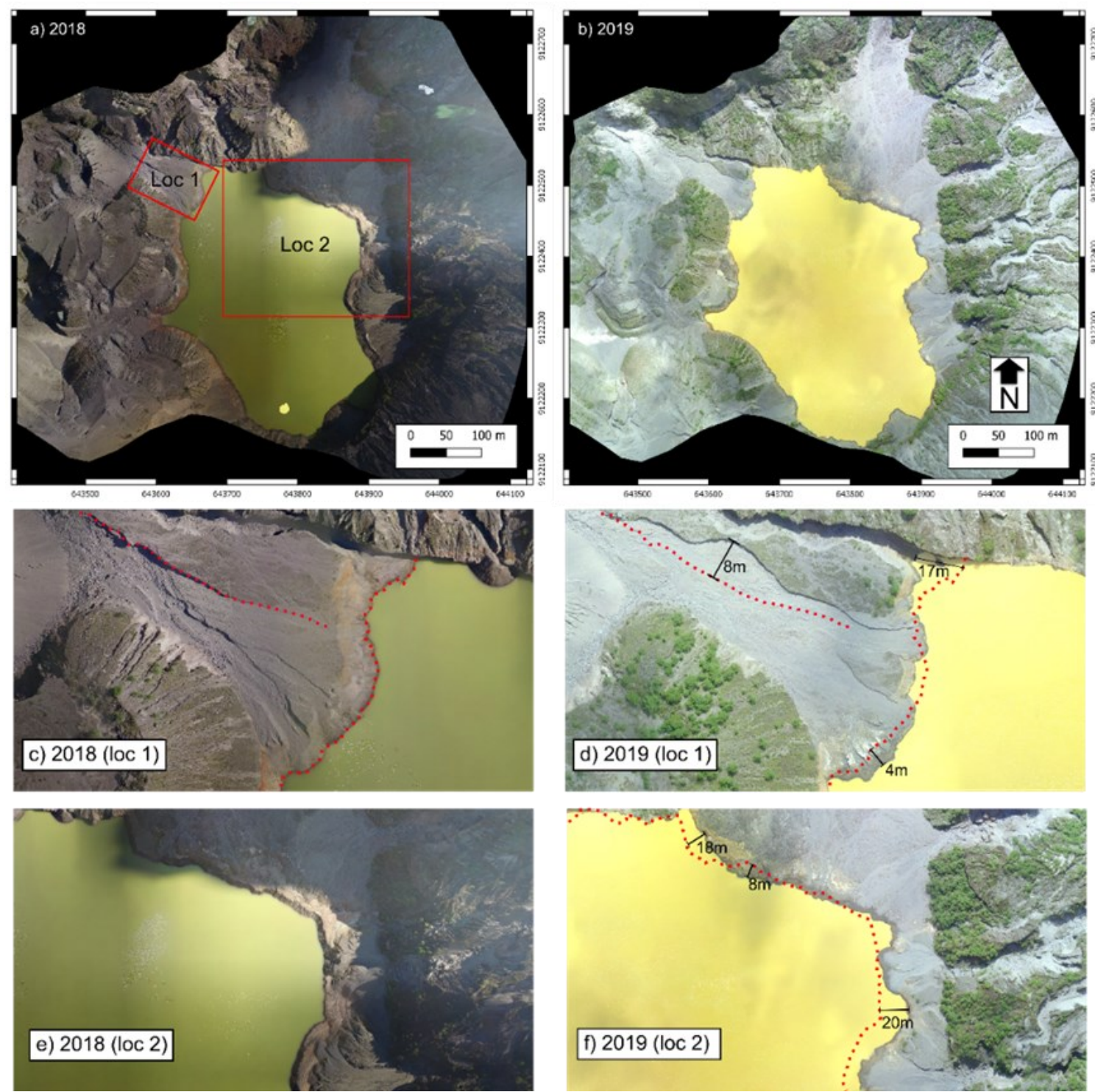

Figure 1. Comparison of photomosaic of aerial images taken by drone in a) 11 September 2018 and b) 16 July 2019 shows the topography changes at the Kelud crater. The color of the water lake changes from green to brown. Gd) Zoomed images at the location 1 and 2 clearly describe the erosion and deposition processes at the Kelud crater. 

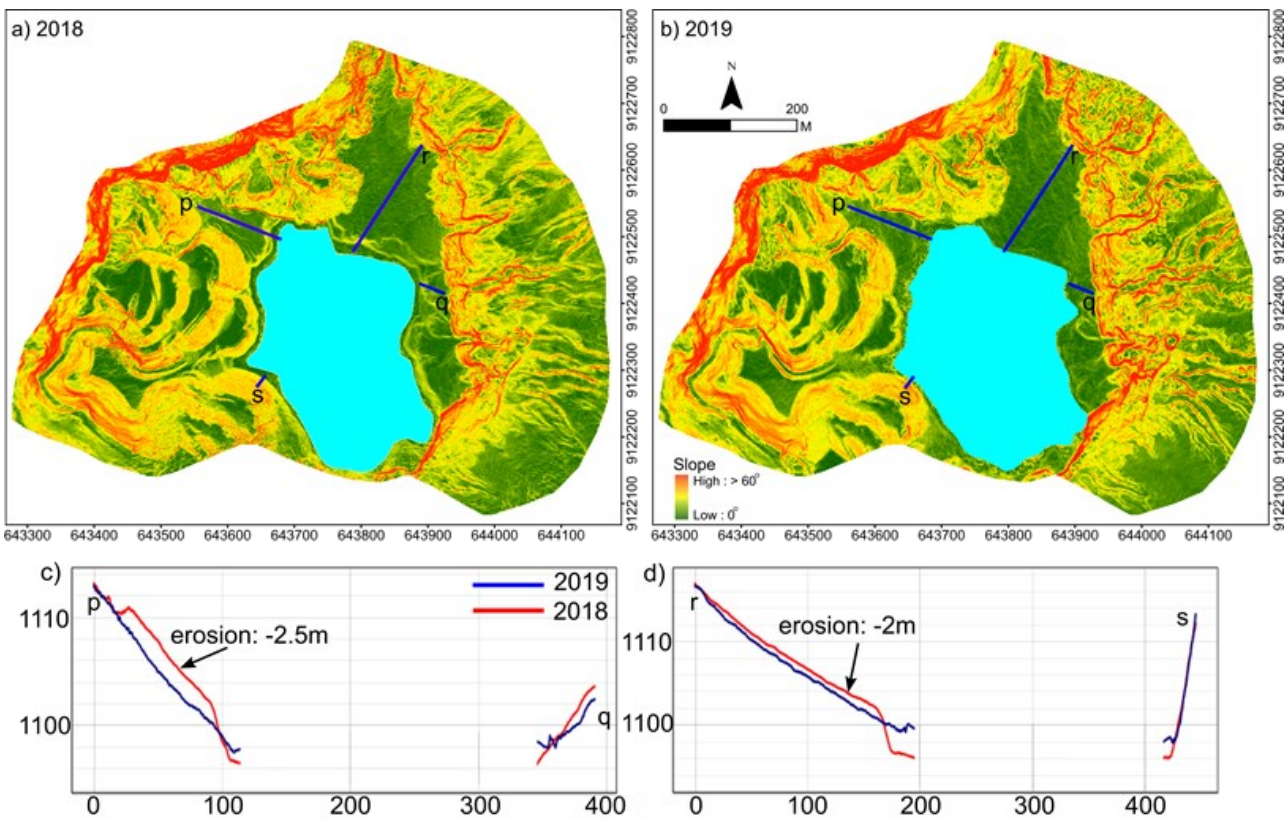

Figure 2. Topography changes at the Kelud crater show the evidence of erosion processes at the Kelud crater that reduce the elevation around $-2 \mathrm{~m}$. The materials were transported and deposited at Kelud crater lake that may increase the water level up to $+3 \mathrm{~m}$.
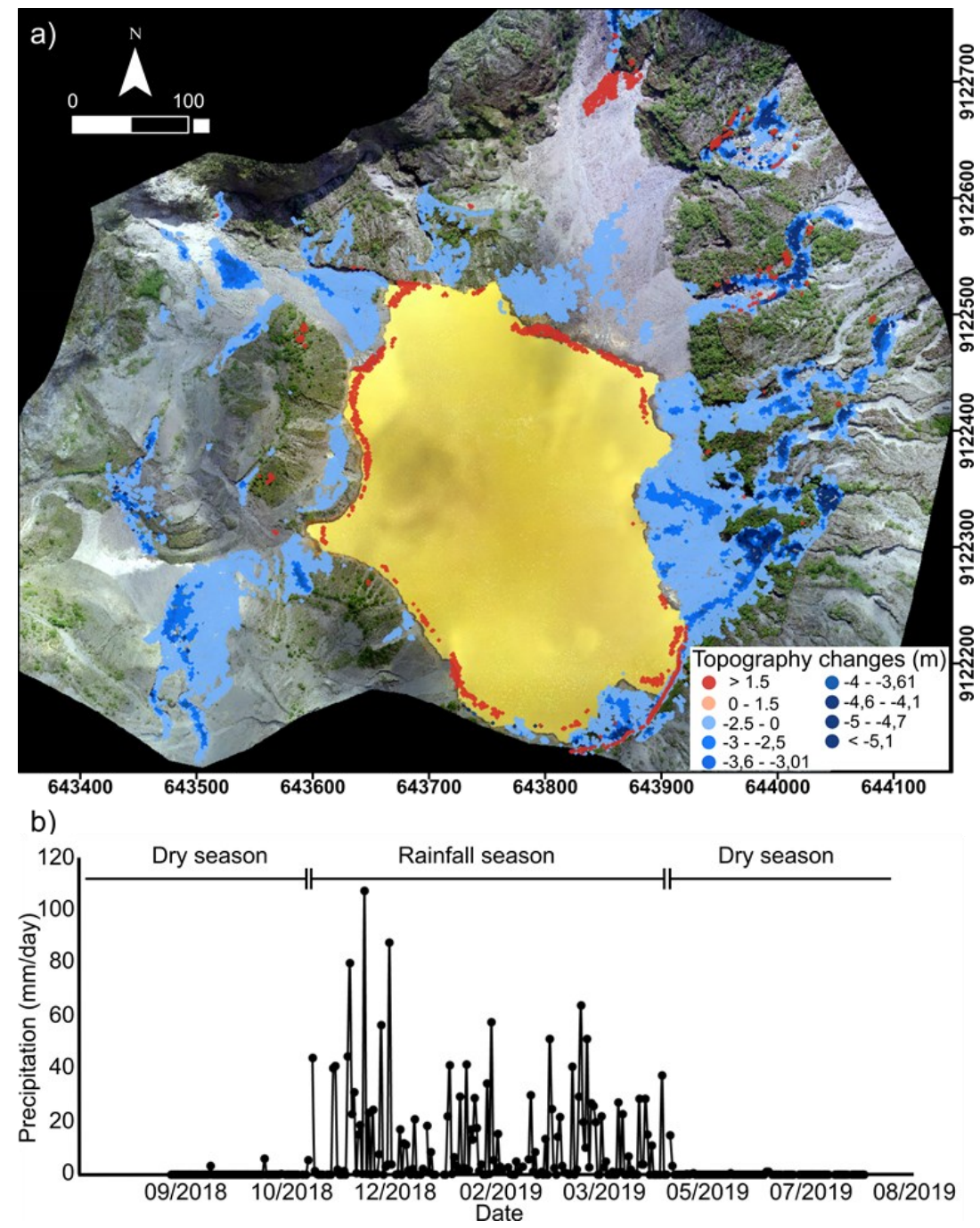

Figure 3a). Map of topography changes shows massive erosion process (indicated by blue color) at the east slope valley of Kelud's crater with maximum elevation loss of $-5 \mathrm{~m}$. The eroded materials were transported and deposited (indicated by red color) around the Kelud's crater lake. b) BMKG’s rainfall weather station located at Malang city ( 27 km from kelud) recorded rainfall between late October 2018 and early May 2019 with maximum precipitation up to 100 mm/day that may contribute to the erosion and deposit processes at the Kelud crater. 


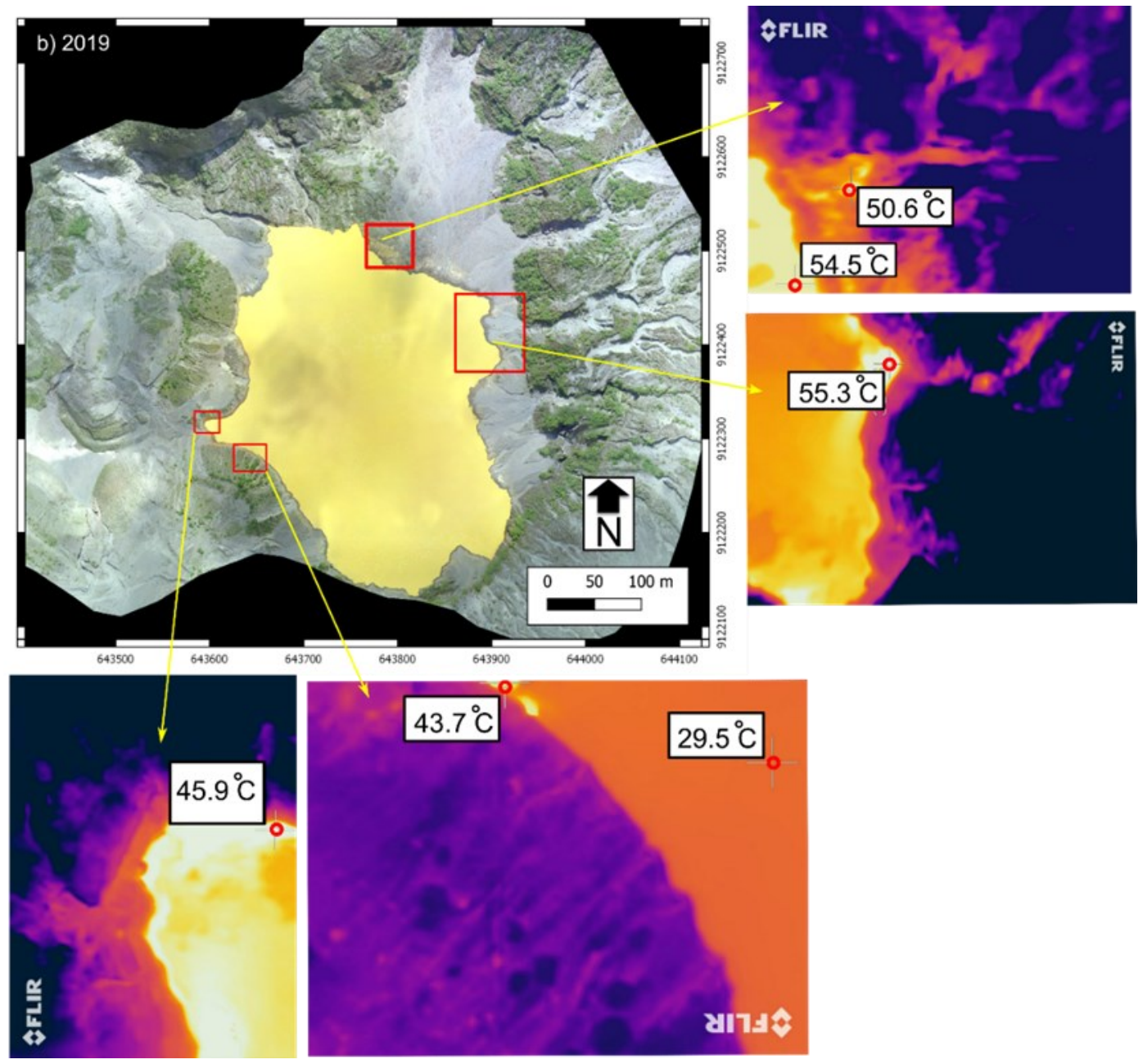

Figure 4. Thermal distribution of the Kelud crater lake observes 4 hot spots at the vicinity of the Kelud crater lake, whichmay indicate active fractures area. The average temperature of the middle Kelud crater lake is $29.5^{\circ} \mathrm{C}$.

Thermal variation at Kelud crater lake

Thermal investigation by using low-cost mobile FLIR thermal camera can provide information of thermal distribution around the Kelud crater lake (Fig. 4). We found four high temperature area at the north (loc 1), northeast (loc 2 ), and west-southwest (loc 3 and 4) vicinity of the Kelud crater lake. The maximum apparent temperature at the location $1-4$ is within a range of $43.7^{\circ} \mathrm{C}-55.3^{\circ} \mathrm{C}$ (Figure. 4). While, the average apparent temperature of the Kelud crater lake is $\sim 29.5^{\circ} \mathrm{C}$.

Our observation through drone thermal camera suggests that the average temperature at the middle of the Kelud crater lake is $29^{\circ} \mathrm{C}$. This temperature is lower than the temperature of the Kelud crater lake prior to the 2014 eruption that reached up to $\sim 60^{\circ} \mathrm{C}$ (Hidayati et al., 2018). The maximum temperature that observed by our drone thermal camera was $54.5^{\circ} \mathrm{C}$ at the north vicinity area of the Kelud crater lake. The hot spots at the north, northeast, and westsouthwest area may indicate active underwater fractures that continuously emit volcanic gasses and transfer the heat by convection process. Our thermal drone image can provide spatial information of thermal distribution that can be used as an evaluation for future volcanic hazard assessment at Kelud volcano.
Deposition processes at the crater lake of Kelud and the potential hazards

A plinian-type eruption with VEI 4 (volume $>100 \times 10^{6}$ $\mathrm{m}^{3}$ ) had changed the Kelud crater as observed by optical satellite imagery taken on 19 May 2014 (shortly after the plinian-type eruption) (Maeno et al., 2016). The plinian eruption produced a crater with diameter of $\sim 400 \mathrm{~m}$ and a small crater lake in the middle of the crater. The Kelud crater lake becomes wider four years later after the 2014 plinian eruption as observed from our drone orthomosaic in 2018. Moreover, the topography of crater causing rain inflow greater than outflow that may increase the water level of the crater lake significantly. The strong inflow at the crater's slope erodes and transports the volcaniclastic materials to the Kelud crater lake and cause deposition that can increase the water level of the Kelud crater lake. Potential hazards due to these natural processes are crater flood that can increase pore water pressures and may trigger dam failure (Manville, Hodgson, \& Nairn, 2007). To mitigate the potential of crater lake flood, the Dutch government built a tunnel close to the Kelud crater to control the lake water level (Van Padang, 1960). When the water level of crater lake increases dramatically, the tunnel work to outflow the water lake up to $2-4.3$ million $\mathrm{m}^{3}$ and effectively reduce number of lahars since the 1951 eruption (Sri Hadmoko et al., 2015). 
Massive deposition at the crater lake floor may also block the volcanic degassing processes and trigger gas overpressure that may lead to an explosion. Our thermal image acquired by drone observe active fracture with temperature up to $54^{\circ} \mathrm{C}$ that continuously release volcanic gasses. We observed continuous bubble at the Kelud crater water lake that related to high temperature area fieldwork. $\mathrm{CO}_{2}$ gas that produced by Kelud magmatic system may cumulate and saturate below the Kelud crater lake. The accumulated $\mathrm{CO}_{2}$ volcanic gas is sufficient to trigger a sudden release of $\mathrm{CO}_{2}$ gas rich that called as a limnic eruption (Gunkel et al., 2008). Such of this $\mathrm{CO}_{2}$ gas rich explosion had occurred in Lake Nyos, Cameroon, West Africa which killed almost thousands of people (Kling et al., 1987).

The color of Kelud water lake has changed between 2018 and 2019 from relatively green to brown as shown in our drone orthomosaic images (Fig. 1). Green color of an active volcanic crater lake is classified as medium activity, while brown color is classified as low activity (Caudron, Ohba, \& Capaccioni, 2017). Therefore, the activity of Kelud volcano possibly decreases between 2018 and 2019 .

\section{Conclusion}

The current activity of Kelud is normal, however, massive erosion that causes deposition around the Kelud crater lake should be evaluated further as potential hazards such as crater flood and overburden gas overpressure at crater lake floor can lead to gas rich explosion. The average temperature of the Kelud crater lake is relatively low with several hotspots observed around the Kelud crater lake with a range temperature of $43.7^{\circ} \mathrm{C}-55.3^{\circ} \mathrm{C}$. This high temperature represents active degassing underwater fractures that necessary to be evaluated for future potential hazards.

\section{Acknowledgement}

This study is funded by Indonesian collaboration research number 633/UN1/DITLIT/DIT-LIT/LT/2019. We also thank to Nia Haerani from PVMBG Bandung, Indonesia, and Khoirul who always support during fieldworks. Thank you for Anas Handaru for helping us during drone data acquisition.

\section{References}

Caudron, C., Ohba, T., \& Capaccioni, B. (2017). Geochemistry and geophysics of active volcanic lakes: An introduction. Geological Society Special Publication, 437, 1-8. doi:10.1144/ SP437.18

Darmawan, H., Walter, T. R., Brotopuspito, K. S., Subandriyo, \& Nandaka, I. G. M. A. (2018). Morphological and structural changes at the Merapi lava dome monitored in 2012-15 using unmanned aerial vehicles (UAVs). Journal of Volcanology and Geothermal Research, 349, 256-267. doi:10.1016/j.jvolgeores.2017.11.006

Darmawan, H., Walter, T. R., Richter, N., \& Nikkoo, M. (2017). High resolution Digital Elevation Model of Merapi summit in 2015 generated by UAVs and TLS. GFZ Data Services. doi:http://doi.org/10.5880/GFZ.2.1.2017.003

Darmawan, H., Walter, T. R., Troll, V. R., \& Budi-Santoso, A. (2018). Structural weakening of the Merapi dome identified by drone photogrammetry after the 2010 eruption. Natural Hazards and Earth System Sciences, 18(12), 3267-3281. doi:10.5194/nhess-18-3267-2018

De Beni, E., Cantarero, M., \& Messina, A. (2019). UAVs for volcano monitoring: A new approach applied on an active lava flow on Mt. Etna (Italy), during the 27 February-02 March 2017 eruption. Journal of Volcanology and Geothermal Research, 369, 250-262. doi:10.1016/j.jvolgeores.2018.12.001

Derrien, A., Peltier, A., Villeneuve, N., \& Staudacher, T. (2020). The 2007 caldera collapse at Piton de la Fournaise: new insights from multi-temporal structure-from-motion. Volcanica, 3 (1), 55-65. doi:https://doi.org/10.30909/vol.03.01.5565

Fisher, R. V., \& Smith, G. A. (1991). Volcaniclastic Processes of Transport and Deposition Sedimentation in Volcanic Settings (Vol. 45, pp. 0): SEPM Society for Sedimentary Geology.

Goode, L. R., Handley, H. K., Cronin, S. J., \& Abdurrachman, M. (2018). Insights into eruption dynamics from the 2014 pyroclastic deposits of Kelut volcano, Java, Indonesia, and implications for future hazards. Journal of Volcanology and Geothermal Research. doi:10.1016/j.jvolgeores.2018.02.005

Gunkel, G., Beulker, C., Grupe, B., \& Viteri, F. (2008). Hazards of volcanic lakes: Analysis of Lakes Quilotoa and Cuicocha, Ecuador. Advances in Geosciences, 14, 29-33. doi:10.5194/ adgeo-14-29-2008

Hidayati, S., Basuki, A., Kristianto, \& Mulyana, I. (2009). Emergence of Lava Dome from the Crater Lake of Kelud Volcano, East Java. Jurnal Geologi Indonesia, 4, 229 - 238.

Hidayati, S., Triastuty, H., Mulyana, I., Adi, S., Ishihara, K., Basuki, A., Kuswandarto, H., Priyanto, B., Solikhin, A. (2018). Differences in the seismicity preceding the 2007 and 2014 eruptions of Kelud volcano, Indonesia. Journal of Volcanology and Geothermal Research. doi:10.1016/ j.jvolgeores.2018.10.017

James, M., Carr, B., D'Arcy, F., Diefenbach, A., Dietterich, H., Fornaciai, A., Lev, E., Liu E., Pieri D., Rodgers, M., Smets, B., Terada, A., Aulock, F., Walter T. R., Wood, K., Zorn, E. (2020). Volcanological applications of unoccupied aircraft systems (UAS): Developments, strategies, and future challenges. Volcanica, 67-114. doi:10.30909/vol.03.01.67114

Kasbani, Gunawan, H., McCausland, W., Pallister, J., Iguchi, M., \& Nakada, S. (2019). The eruptions of Sinabung and Kelud volcanoes, Indonesia. Journal of Volcanology and Geothermal Research, 5-9. doi:10.1016/ j.jvolgeores.2019.07.008

Kling, G. W., Clark, M. A., Wagner, G. N., Compton, H. R., Humphrey, A. M., Devine, J. D., Evans, W. C., Lockwood, J. P., Tuttle, M. L., Koenigsberg, E. J. (1987). The 1986 Lake Nyos Gas Disaster in Cameroon, West Africa. Science, 236, 169-175. doi:10.1126/science.236.4798.169

Lague, D., Brodu, N., \& Leroux, J. (2013). Accurate 3D comparison of complex topography with terrestrial laser scanner: Application to the Rangitikei canyon (N-Z). ISPRS Journal of Photogrammetry and Remote Sensing, 82, 10-26. doi:10.1016/j.isprsjprs.2013.04.009

Maeno, F., Nakada, S., Yoshimoto, M., Shimano, T., Hokanishi, N., Zaennudin, A., \& Iguchi, M. (2016). A sequence of a plinian eruption preceded by dome destruction at Kelud volcano, Indonesia, on February 13, 2014, revealed from tephra fallout and pyroclastic density current deposits. Journal of Volcanology and Geothermal Research, 1951. doi:10.1016/ j.jvolgeores.2017.03.002

Manville, V., Hodgson, K. A., \& Nairn, I. A. (2007). A review of break-out floods from volcanogenic lakes in New Zealand. New Zealand Journal of Geology and Geophysics, 50, 131150. doi:10.1080/00288300709509826

Mastin, L. G., \& Witter, J. B. (2000). The hazards of eruptions through lakes and seawater. Journal of Volcanology and Geothermal Research, 97, 195 - 214.

McGonigle, A. J. S., Aiuppa, A., Giudice, G., Tamburello, G., Hodson, A. J., \& Gurrieri, S. (2008). Unmanned aerial vehicle measurements of volcanic carbon dioxide fluxes. Geophysical Research Letters, 35. doi:10.1029/2007GL032508

Nawiyanto, \& Sasmita, N. (2019). The eruption of Mount Kelud in 1919: Its impact and Mitigation Efforts. Paper presented at 
the $1^{\text {st }}$ International Conference on Social Sciences and Interdisciplinary Studies (ICSSIS).

Sri Hadmoko, D., Samsu Rijal, S., Arida, V., Ratih, Mertiara., Herumurti, S., Estuningtyas, W. M., Dyah Rachmawati, H. (2015). Lahar impact to the landuse along Konto river after Kelud eruption 2014. Paper presented at the $7^{\text {th }}$ International Graduate Students and Scholars Conference in Indonesia (IGSSCI), Universitas Gadjah Mada, Yogyakarta.

Szeliski, R. (2010). Computer Vision: Algorithms and Applications. 1 - 979.

Van Padang, M. N. (1960). Measures taken by the authorities of the vulcanological survey to safeguard the population from the consequences of volcanic outbursts. Bulletin Volcanologique, 23(1), 181-192. doi:10.1007/BF02596643

Waythomas, C. F. (2001). Formation and failure of volcanic debris dams in the Chakachatna River valley associated with eruptions of the Spurr volcanic complex, Alaska. Geomorphology, 39, 111 - 129. 